\title{
Where in the World Are We? Elections, the Color Line, the Decline of Empire and Fireflies
}

\author{
Bernardine Dohrn
}

My middle son, Malik, was five-years old when my life partner/his father Bill got his doctorate. All four of us waited outside during Bill's dissertation defense with balloons and flowers. When Bill came out, Malik raced over to him, jumped up into his arms and then said, "Poppy, you're a doctor, right? But you're not the kind of doctor who can help anyone." [1]

That, of course, remains the dilemma for all graduates. You graduates are, we anticipate, the kind who can help.

Where in the world are we?

The graduating classes of Summer 2005 entered college or high school just at the turn of the millennium in the long-ago autumn of 2001, looking forward with the promise and privileges of stepping forth from the richest, most powerful, globally-dominant nation in human history. You have — as young adults today_almost no memory of the cold war, let alone a time of American isolationism or economic depression. You were awash in abundance relative to the rest of the world, even those of you who worked and sacrificed to graduate. You were raised in, soaked in, and shaped by an era of American triumphalism, empire, privilege, and apparent peace.

Yet you have graduated, just four years later, with that myopic worldview in ashes. Just as you began your student years, the brutal, criminal attacks of September 11, 2001 tore open the illusions; the shredded economy and loss of jobs, the consequences of deregulation and devolution that bankrupted state and local governments, the relentless punishment and imprisoning of over two million of your fellow citizens in America, flagrant corporate plunder and criminality, rolling blackouts, the apparently permanent war on terrorism, the shock and awe occupation of Iraq, systematic and degrading detention without trial, torture, and extrajudicial assassinations, and the establishment of a crescent of new U.S. military bases across the Middle East and South Asia—all have transformed whatever blissful myths were harbored as you prepared to enter college or high school.

Yet you graduates were not sound asleep. Many, during your past four years, have been struggling to come awake to a world in flames. Although your school years were characterized by the colossal new world ordering of war and occupation, you also came to connect with the ripples of insurgent resistance to power, the so-called "globalization from below"- manifest in the world social forums in Puerto Allegre and Mumbai, the international movement to abolish violence against women, the global effort for a safe environment, the surprisingly fierce partnerships for human rights, insurgent public health efforts to address the HIV-AIDs epidemic, the U.N. Durban Conference on Racism and Xenophobia, the campaign to abolish child soldiers, the popular peasant struggles against being charged for water in Bolivia, the Bolivarian revolution in Venezuela, and the monumental global opposition to war on February 15, 2003. These are the incipient and activist communities with global reach who simultaneously represent the humanist alternative, the emancipatory.

The inability to stop the war in Iraq flowed into popular efforts to defeat Bush's '04 re-election.

This year, hundreds of thousands of young people had their first experiences with organizing, with talking politics to strangers, with knocking on doors in neighborhoods, with working a campaign in the buildup to the 2004 
Presidential election. We had Barack Obama, swing weekends, and United for Peace and Justice, the RNC convened under siege in New York City, Move On, Code Pink, and Michael Moore. That is the good news. The bad news is that this monumental effort, media savvy, and creative hope did not go into building an independent radical movementthe only force that results in substantial change. The work was wiser than previously, the sectarian squabbles diminished and the tactical divides bridged - but the organizing did not (at least in the short run) feed into a stronger, more robust and effective radical movement. We know that real change comes from below. Lincoln did not free the slaves, Franklin Delano Roosevelt did not legalize unions, forge a social security net or end the depression, and LBJ did not support civil rights_-without massive, independent and radical social movements insistent on justice, none of these presidents would have made those meanings in those particular moments of crisis and choice. So we have a choice: we can ride the waves of despair and powerlessness after November elections, or we can work to rebuild and recreate an independent, radical, participatory democratic movement.

Just thirty years ago, in the village of Ban Me Thuot at the Southern end of the Central Highlands, the South Vietnamese army broke and ran, tearing off their uniforms and returning to their homes as quickly as possible. The North Vietnamese and NLF (National Liberation Front) forces raced toward Than Son Hut airbase and Saigon where four days later they took the Presidential Palace and seized the former U.S. embassy where U.S. authorities frantically shredded documents and dollars, beat back their South Vietnamese allies and employees, and climbed from the roof onto the final evacuating helicopter. It was to be, despite the relentless predictions of a communist bloodbath, a relatively peaceful end to the U.S.'s longest war.

In the subsequent long War to Explain the War since that traumatic, final rout, the massive U.S. military/ political defeat in Vietnam after twelve years (and five different presidents) of invasion, occupation, pillage and Vietnamization, is still in contention here in the "belly of the beast." This year, the media barely ran the footage of the U.S. final days in Vietnam on TV news or blogs, or the front pages, or the endless talk shows. It would be too eerie for the 150,000 U.S. troops today occupying Iraq with an analogous inability to "win." It would reilluminate the palpable vulnerabilities of overwhelming technical, military power. So our memory of that U.S. defeat more than a quarter of a century ago must be smudged, erased, recast, and revised. That defeat, it is claimed, was caused by the Failure to Stay the Course; it was that The Military Was Shackled; it was the Treason Within, not the contradictions of empire and resistance. So the tale is retold, and the veterans who returned to tell the truth—as today-are ridiculed and dismissed for their most heroic moments.

The wonder is that we (the broad "we") as a people assumed responsibility for what was being done in our name-for the role of our government in Vietnam, South Africa, Nicaragua, and Haiti and built an authentic, aroused and engaged opposition that grew and was sustained. Today, that is a memory which must be buried, rendered invisible, or criminalized and discredited. For all its limitations and although we were unable to stop the Vietnam War even when a large majority of the American people opposed it, that resistance remains an example of popular democratic activity which toppled two presidents and left behind a legacy which survives_even post $9 / 11[2]$. Then as now, the administration failed to win hearts and minds, either in the country of occupation, or at home.

And then, as now, election cycles interrupted the anti-war and Black Freedom Movements, seduced young people to become active for the Least Worst Alternative, and led to crushing defeats for more "moderate" or antiwar candidates. The elections did not change the outcome of war or white supremacy: both were always bipartisan projects. They did not change the enormous unpopularity of the war-people massively opposed the war and were confident that the government was lying to them both before and after the election. Racism and the haunting legacy of slavery was to characterize much of the election discourse then and again today. Of course, we now talk race in a coded manner, rather than the crudities of the 1964 and 1968 Democratic and Republican National Conventions. But the understanding is universal: crime talk is race talk; fear talk is race talk; immigrant talk is race talk; and anti-gay talk is hate talk.

Reverend Martin Luther King, Jr., at his most radical the year before his death, said: "The greatest purveyor of violence on this earth is my own country." That was 38 years ago. His words are as true in the twenty-first century. Today, with a revived empire and permanent war as the shape of U.S. triumphalism and barbarism, the occupations of Iraq and Afghanistan and a massive U.S. geopolitical unilateralism are spreading military outposts across Eastern Europe, the Caucasus, Central Asia and the Subcontinent, the Middle East, and the Pacific Rim. The goals include domination of oil and natural resource reserves by assuring supply and access, markets, labor, and investment; policing "unfriendly" or terrorist regimes and rebellious or independent nations; protecting U.S.-friendly regimes; 
and containing and weakening China and India. It includes political and financial intervention in the democratic Bolivarian revolution of Venezuela, the militarization of Colombia, and the isolation of Chiapas. It involves a deadly quest for cultural and political hegemony.

Your parents and I, the so-called Sixties generation, were absolutely certain that we would leave you and our grandchildren a legacy of a better, more just, world. So much for certainty. You entered school on a privileged wave, but you step forth into a greater challenge — a more treacherous, unequal, divided, and inflamed global moment than the one we faced forty years ago.

So you will embrace your own time. You will live and have your breathing in the eye of this whirlwind.

And this is a breathtaking moment in American life. In large part, we North Americans don't know who we are and we don't know where we are.

Since $9 / 11$, it is irrefutably apparent that we are a geographically challenged people. We are famous throughout the world for having trouble locating ourselves in time and space. I ask my students to locate Afghanistan on a map. Consternation. I challenge myself and them to draw a free-hand sketch of the six countries bordering Iraq. Pandemonium.[3]

National Geographic did a survey of 18-25 year old Americans and discovered that 85\% could not locate Iraq. But $29 \%$ could not locate the Pacific Ocean, and even 11\% of young Americans could not point to the United States on a map of the world. Michael Moore says that there ought to be an international law that says no one can bomb a country they can't find on a map. Such a law would lead to a precipitous drop in violence around the world.

I was in Rwanda with fifteen law students, my life partner Bill, and my son Chesa during the tenth anniversary of the genocide. In that sorrowfully beautiful country, a million people were killed in 100 days while the United States and world powers refused to use the "g" word [genocide] and failed to take the most simple, nonviolent steps to stop the slaughter.

In Rwanda, Chesa organized a visit to a dusty refugee camp on a barren hillside of 15,000 stateless people in Rwanda, half of them-like all refugees-children. There, a youngster in a mud floor classroom reached into his desk and pulled out a freehand map he had drawn of the world. On his map, this fourteen-year old pointed out Chicago. Chicago and North America are important to him. He needs urgently to know both where he is and where we are.

Who in the world are we? I ask my students: Is this a historic moment?? To a person, they think it is not. History is Nelson Mandela, Ella Baker, and Rosa Parks, or generals, inventors and presidents. It is the opposition to slavery and lynching, or to the gulags of Hitler and Stalin.

When Muhammad Ali refused to be inducted into the U.S. army and told the world, "no Vietcong ever called me nigger," he took the loneliest of decisions. No focus group approved, no foundation funded, no friends, family members, religious leaders or entourage supported him. And he did not know how it would turn out — that he would be recognized as a hero across Africa and around the world, and eventually recast here, decades later, as a great, cuddly lion.

So you act and take a stand, without knowing the outcome. You keep in play both the sense of opposition to systems of power, and your sense of engaged participation. Act with confidence yet simultaneously with the irreconcilable tension of the certainty that you will not be entirely right.

But this moment, your moment, is historic and pregnant with possibility. There is nothing inevitable about the final outcome of the occupation of Iraq, the acceleration of global warming, or the perpetuation of the world's richest $1 \%$ receiving as much income as the poorest $57 \%$. These are human constructions and they can be transformed by human beings, acting both ethically and in concert.

One obstacle to your seizing this historic moment is the mythmaking about the Sixties.

Our son Malik once called out from the back seat of the car, "Pops, tell us the story about when you burned your credit card." "Whoa," said Bill, "I wasn't that radical! I burned my draft card but I need my credit card."

In too many ways, lore and legend about the Sixties can be a bludgeon, a barrier, and an obstacle for your generation. This is no time for nostalgia, and I surely am not urging you to do as we did. Your parents, your schools, your capable faculty have given you their best. Most of what you now need, we never knew or forgot to tell you.

When my son Zayd came back for Thanksgiving after his first two months away at college, he turned to me at our crowded, family holiday meal — and as the room seemingly fell silent he said, somewhat accusingly, "Mom, why didn't you tell me about Kierkegaard?" Touche. I read him all of Dickens, took him to every Shakespeare play, and at the last minute I even remembered to teach him how to iron, but Kierkegaard... 
We are all works in progress, unfinished, and still learning. If every moment is historical, you are not a passive object of history but a subject in history. You too are makers of history.

Who in the world are we?

At the turn of the last century, W.E.B. DuBois famously wrote that the issue of the twentieth century would be the issue of the color line.

51 years ago, an extraordinary and unpredictable development resulting from decades of human initiative occurred. On May 17, 1954, the justices of the Supreme Court issued a unanimous decision that shattered the cultural assumption of white supremacy and black inferiority. Its import cannot be overestimated. The U.S. Supreme Court overturned its own shameful history. It acknowledged 250 years of slavery and 100 years of Jim Crow. The decision in Brown v. Board of Education-actually five cases_imagined a nation of equal justice under the law.

That promise - and the triumph of a heroic group of parents, students and civil rights attorneys who toiled over two decades to breech that wall, to open up doors through which they could not travel—was immediately undercut by Brown II. "All deliberate speed," it turns out, came to mean "slowly." Brown II was a green light to subvert the equality ideal—and 50 years of hostile undermining of Brown followed: closing public schools, angry mobs confronting children, busing crises, reverse discrimination arguments, new forms of racial heirarchy, and schools now more highly segregated than ever. So today, we together face an incomplete revolution by the Black Freedom Movement - nine times as many African-Americans in prison today as in 1954 - an equivocal reality that spills over into your century.

So what will be the issue of the twenty-first century? That critical question-how you will judge yourself and how history will judge you - is yours alone to identify and to seize. To fail to do so, to act as though we are at the end of history, is to submit to power, to perpetuate the silence of inequality and pain at home and abroad.

One great challenge of the twenty-first century will be to face the prospect of a declining American empire, the end of U.S. hegemony, the emergence of a multipolar world, and to face it with imagination and hope. It is likely that a half century from now the United States will not be a sole hyperpower, alone dominating the globe not only militarily but economically and culturally. Can we imagine such a future as an extension of human potential, an innovation, an opportunity, rather than an embattled, bitter decline?

Today the U.S. population is some $4.9 \%$ of the world's people but controls some $60 \%$ of the world's wealth, a certain formula for instability and crisis.

Can we anticipate a United States as one nation among nations, as a complexity of peoples and traditions, religions and narratives who have great inventions and unique strengths to offer the world community (we can start with jazz, baseball and the Bill of Rights)? Could your creativity in the sciences, philosophy, and international law prepare us for the possibility of participation without the unchecked imperative to dominate and subjugate? That will require, I caution, radical imagination. The answer is critical since the revival of civil society and human survival hang in the balance.

Yet, sober as the stakes are, don't forget the necessity of laughter. Humor stimulates the imagination and humor is generous. At the monumental women's march in June 2004, the Radical Cheerleaders wore pink panties over their clothing and on the panties was written: "weapons of mass seduction." We need the Onion, Aaron McGruder, and the Daily Show to give shape and voice to the contest between powerful systems of interests and the less powerful. A recent Onion headline read: "Massachusetts ups the ante: you can only marry people of the same sex." It carried a picture of two glum, anxious-looking guys, one saying, "I wanted to marry my girlfriend but I live in Massachusetts; I have to marry this guy."

The spoken word, theater, the arts, and the web can seize back the now-appropriated language of human rights, democracy and freedom, and reconnect them to complex and yeasty realities. Your imagination is as critical to resistance as are demonstrations, meetings, and leaflets. We have the stranglehold of consolidated corporate media and imbedded reporters, yet the insurgent and transgressive truth-telling of digital cameras and web videos breaks free from censorship and constraint. The connective tissue of what Jonathan Swift called "oratorical machines" now give us immediate access to Arundati Roy, Susan Sontag, Wole Soyinka, Rashid Khalidi, and Samir Amin—that imagined but actual, incipient community of independent intellectuals who yoke themselves to the sorrow and suffering of ordinary people.

Our biggest obstacle to forging an alternative tidal wave is the relentless drumbeat that tells us that what we do won't make a difference. Our own sense of despair or worse, cynicism, is a monumental, invisible barrier to social justice. President Bush, like Nixon before him, came out from the White House to announce to the press that he did 
not notice the tens of millions in the streets across the world demanding peace and justice just before the invasion of Iraq, or the half million people in New York at the RNC. The press conference to say that it didn't matter. I think he noticed.

We are meant to feel marginalized and diminished, to retreat to privatized silence and slumber. We are encouraged and enticed not to act as if every human life is equally valuable: lives in Srebrenica, in Haiti, in the Sudan, Guatemala, South Central L.A., Palestine and Israel, and Oklahoma. We are intimidated into not acknowledging the humanity of the "enemy" or the "other."

But in my lifetime, young people have changed the world. They changed the world in Little Rock, Arkansas, in Selma, Alabama, and in Soweto. No one of us ever thought we would see a free and democratic South Africa in our lifetime. Yet, the young people of Soweto could not wait; against the wishes of their parents and teachers, without leadership from the African National Congress, with only their own urgent reading of their moment, they catapulted forward the end of apartheid. Young people changed the world at Tien An Mien and perhaps in Seattle. Young women, veterans, gays and lesbians, immigrants, and disabled activists too numerous to mention have transformed our landscape and shaped a world we readily take for granted.

Young people move us toward justice.

You can, each of you, open your eyes, go out to talk to people, learn from them and teach. I urge you to go outside your comfort zone, put yourself regularly-even just once or twice a week-with the dispossessed. Share food, listen hard, see how you can be changed and what you have to offer.

I wish for you just this: the courage to speak truth to power, the grit to become a witness to persecution and suffering, the audacity to be a dissenting voice in all conflicts with authority. And being a Midwest gal from the generation that wants it all, I also-we also-desperately want for you the sweet promises of fireflies in the summer, wondrous adventures, abundant love, and the pleasures of solitude.

The Irish poet Seamus Heaney wrote:

History says, don't hope

On this side of the grave

But then, once in a lifetime

The longed-for tidal wave

Of justice can rise up

And hope and history rhyme.

May we all experience that longed-for moment, where hope and history rhyme.

\section{Endnotes}

1. This article is adapted from a commencement address given by the author at Pitzer College.

2. The civil rights/anti-war legacy includes: serving as the cradle for multiple and radical movements (the women's movement, gay and lesbian movement, environmental movement, disability rights movement, the Puerto Rican independence movement, new labor organizing, and immigrant rights), the abolition of the draft, the Watergate "impeachment" of Nixon, exposure of the massive, secret, illegal FBI and CIA counterintelligence operation [COINTELPRO] that included assassination of Black Panther Party members, trumped-up charges, and dirty tricks (Deep Throat, Mark Felt himself, was convicted of these crimes and later pardoned by President Reagan), the War Powers Act and international law as constraints, and the failure to make movements illegal, despite some ten major conspiracy indictments, a Justice Department grand jury strategy, COINTELPRO assassinations and convictions, and the continued jailing of political prisoners.

3. The answer: Turkey, Iran, Jordan, Kuwait, Syria and Lebanon. 
